\title{
Marketing and Branding of Teacher Education in Khyber Pakhtunkhwa, Pakistan: Teacher Education Providers' Struggles for Prospective Entrants
}

\author{
Gulab Khan* \\ Asif Khan ${ }^{* *}$ \\ Munazza Sultana***
}

\begin{abstract}
Pakistan's National Educational Policy 2009 delineates that quality of teacher certifications in primary and secondary tiers of education will progressively be made more rigorous by replacing the erstwhile Primary Teaching Certificate (PTC) and Certificate of Teaching (CT) programs. For this and similar policy provisions, in the last two decades, Pakistan has witnessed a rapid increase in the number of private and public Teacher Education Providers (TEPs) that provide alternate and supposedly more rigorous certifications such as the Bachelor of Education. As a result, struggles have ensued among the TEPs to bag their market share of the potential applicants to their teacher education programs. This study explores the struggles and battles of the TEPs in Khyber Pakhtunkwha (KP) province of Pakistan to attract potential applicants to their teacher education programs. Using an exploratory mixed method design, the study analyzes the educational and admission ads published in the three most circulated dailies in KP, namely Mashriq, Express, and Aaj. Findings show the private TEPs taking a lead in the battle against their public counterparts. Policy implications for quality, access to, and branding and marketing of teacher education have been explored and discussed.
\end{abstract}

Keywords: teacher quality, teacher education, educational policy, marketing, branding

\footnotetext{
* Assistant Professor, School of Education, Lahore University of Management Sciences. Email: gulabkhan.nabi@gmail.com

** Assistant Professor, Karakorum International University. Email: asif.khan@kiu.edu.pk ${ }^{* * *}$ Assistant Professor. National University of Modern Languages, Islamabad. Email: msultana@numl.edu.pk
} 


\section{Introduction}

Limited research is available on marketing and branding of educational programs in Pakistan. On the contrary, in the western contexts this area has extensively been explored as the marketing and branding has become a key promotional levers of academic programs. Following the suit and amid a growing interest in reforming teacher education in many countries (Darling-Hammond, Holtzman, Gatlin, \& Heilig, 2005), marketing and branding has made headways into teacher education as well. In response to such global trends as well as domestic needs in teacher workforce, Pakistan has been making efforts to align its teacher education agenda with the international standards and benchmarks. In a hope to come at par with the international standards and benchmarks, policy makers in Pakistan have adopted a neoliberal approach to offering teacher education by allowing private sector to have its footprints in the sector. Resultantly, a significant surge in the TEPs, more so in the private sector, is visible across the country. With a rapid growth in the TEPs, marketing and branding has become a ubiquitous phenomenon to attract prospective entrants to teacher education programs. In this light, this study explores marketing and branding strategies by the TEPs by zooming in on the issue in the province of Khyber Pakhtunkhwa (KP) in Pakistan.

Pakistan's National Education Policy [NEP] 2009 (MoE, 2009) stipulated that "A Bachelor's degree, with a B.Ed., shall be the requirement for teaching at the elementary level. A Masters level for the secondary and higher secondary, with a B.Ed., shall be ensured by 2018..." (MoE, p. 42-43). Similarly, in the consultation meetings for policy review of the NEP 2009, it was reiterated that trainings should be provided on the basis of national professional standards for teachers (Idara-e-Taleem-o-Aagahi, 2016). Similar policy recommendations in the last two to three decades have increased the need to train a largely uncertified teacher workforce. For example, according to AEPAM (2017), $57.1 \%$ teachers in KP have a primary teaching certificate (PTC), certificate in teaching (CT), or are untrained altogether. This suggests that a potentially huge market exists to bring revised teacher education qualifications to nearly $60 \%$ of the teaching workforce in KP. This potential in the teacher education market has resulted in a significant increase in the number of TEPs in the country.

In Pakistan, in 2005, there were 135 teacher training institutes (public $=114$, private $=21)($ Academy of Educational Planning and 
Management [AEPAM], 2006) whereas this number in 2017 increased to $213($ public $=157$, private $=56)($ AEPAM, 2018). This is a $57.8 \%$ overall increase in TEPs in a decade with $166.7 \%$ increase in the private sector alone and $37.7 \%$ in the public sector. Among the 213 TEPs in the country, KP has 41 with 27 in the public and 14 in the private sector in 2017 (AEPAM, 2018). Even though the number of TEPs has increased in the country, enrollment trend shows that the number of potential entrants has increased exponentially (AEPAM, 2018).

This growth in the TEPs has resulted in public and private actors ramping up their efforts to increase respective shares in the teacher training industry in the country. This battle for prospective entrants is manifest in the number and variety of admission and promotional ads on the road side billboards, in electronic and print media, social media platforms, and other more traditional means such as through the word of mouth and alumni branding. As of now, it remains unexplored as to how the TEPs are engaging in efforts to attract potential entrants to their academic programs. It also remains to be seen whether public and private TEPs vary in their strategies and tools to brand and market themselves. An understanding of these and similar dynamics is important to see if public or private sector may potentially dominate the teacher education market in the years and decades to come.

In Pakistan, while authentic and updated figures ascertaining newspaper readership is not available, anecdotal evidence suggests that a large portion of general public still uses newspapers to access news and information in Pakistan. This is observed in the form of newspaper stands actively selling newspapers in addition to the door to door distribution of the printed newspapers. Lately, almost all major dailies in the country have adopted digital platforms, in addition to print, to increase their readership. The digital platforms thus have facilitated millions of smartphone users who, in the wake of declining Internet rates and increasing speeds with the availability of $3 \mathrm{G}$ and $4 \mathrm{G}$ services in almost every city and town in the country, can now easily access and read a number of dailies online. With this at the forefront, this article explores how the public and private TEPs (called advertisers interchangeably throughout this article) engage the newspapers with print and electronic versions to attract potential applicants to their programs. The next section presents a snapshot of the literature on the subject. 


\section{Literature Review}

Gaps in the teaching and learning in K-12 settings in Pakistan is largely attributed to the qualifications of the teachers and the traditional teacher development programs (USAID, 2006; Khan, 2010). These circumstances have led to the introduction of new teachers' development programs called Advance Diploma in Education (ADE) and B.Ed. programs through the public and private sector TEPs in Pakistan. Since these programs are at the infancy stage, limited information about the productivity and contribution of these programs are available. Likewise, limited information is available regarding the marketing and branding strategies of various TEPs in the country.

Around the world, a positive growth in enrolment in higher education has motivated the universities to use different strategies to attract maximum number of students to their programs. According to Hanover Research (2014a), branding and marketing has become an increasing focus of institutions in recent years to the extent that specialized personnel are hired and significant amounts of money and time are invested in the process. This elevated focus goes parallel to an increase in the significance of portraying and branding to make their case ".... differentiating and compelling" (Hanover Research, 2014a, p. 5).

Gupta (2010) stated that with the inception of concept of knowledge society, the practice of branding of educational programs has gained much popularity. He further adds that in higher education, branding entails such factors as academic offering, experience of students, prestige of institution, and other factors. It has been suggested that the promises made by the institutions about their programs must be fulfilled and executed through teaching learning processes, learning experiences, and information sharing and human communication (Black, 2008). The universities can achieve this objective by adopting branding strategies that can help them and their affiliated colleges to introduce themselves to the audience to understand who they are and what they do best (Teichler, 2003).

Literature provides multiple interpretation of branding. For instance, Balmer (2001) considers that organizations propose branding as explicating their identity to the audience. Likewise, American Marketing Association 
[AMA] (1960) as cited in de Heer et al. (2015) refers branding as a coherent symbolization that identifies the contenders as offering better services or products than the competitors. From the above mentioned interpretations one can say that branding is a systemic effort to introduce products and services to the targeted audience. However, the concept of branding in the context of educational institutions is different from other businesses and services. Popesscu (2012) points out that branding in higher education is at variance with its concept and practice in business environment. For Black (2008), “...branding in higher education is about people, not necessarily limited to a particular product or service offering in the marketplace" ( $\mathrm{p} 498$, quoted in POPESCU, 2012). Furthermore, academic reputation of an institution is usually equated with the brand name it carries and that formulating a meaningful brand entails defining the mission, central ethos and values of the organization (POPESCU, 2012).

Marketing and branding of educational programs have become an integral component of higher education in the western countries especially in the United States and other advanced countries where marketing experts are appointed to devise strategies for the branding of their programs. This is because research suggests that effective branding can attract stakeholders such as students and staff as well as help raise funds and increase media presence of the institution (University Business, 2008). However, such efforts are only now gaining a gradual momentum in the context of developing nations. Unlike the branding of universities and their programs in the developing countries, fashion branding is substantial and significant in these countries. Researchers attribute the lack of branding and marketing higher education to a lack of awareness on the part of university management in higher education. de Heer and Tandoh-Offin (2015) pointed out that the university management and decision makers in less developing nations have limited knowledge and information about the benefits and advantages of branding in higher education. They further add that research endeavors in developing nations are only limited to specific areas such as factors influencing the choice of university whereas in the developed nations variety of topics are the focused such as communication of university brands, branding policies, international branding, the pros and cons of branding, to name a few. In this regard, Papadakis (n.d) claims that within an institution, departments act as distinct ecosystems with peculiar culture that revolve around the specific subject areas. These peculiarities and nuances generate specific branding strategies that 
highlight the wholesome identity of the department and its constituents such as the faculty, students, curriculum, teaching, and learning processes. The advent of globalization has not only increased the competition internationally among the educational institutions but also within the states where there is a fierce competition which has led the educational mangers to pay greater attention to the branding of their programs and institutions (Chapelo, 2010; Dooley, 2013). Research suggests that links exist between how institutions successfully manage themselves and their brand image. To this effect, one of the most challenging task for the educational managers is to promote a brand that manifests clearly and corresponds well the institutional values and clients' wishes and standards of satisfaction (Valtere, 2010). Popescu (2012) pointed out that as compared to the branding of products, branding of organizations and their services seems to be a more complicated process because in organizations the attitudes, beliefs, and values of people largely affect the branding processes.

Attracting good students and best faculty can bring so many dividends to universities in the form of good revenues and popularity. Both the popularity and revenue have played an important role in the establishment of sub campuses of the top notch universities of North America in foreign countries especially in the Middle East such as Carnegie Mellon University and others. Therefore it has been suggested that the universities and s should give more attention to four principles while branding their programs: a) listen to what is being said about you, and know where you stand, b) understand the competitive landscape and determine what sets your school apart, c) define what you want to stand for and preserve and embrace both the tangible and intangible elements that make your brand unique, and d) be true to who you are, and deliver your brand seamlessly across all touch points (Sullivan, 2012).

According to Bamoriya (2013), there are two stages of branding of an academic program or institution: a) brand development through distinctive promises, and b) approaches of brand promotion. While explaining the brand development through unique promises, he asserts that promises should be evidence based, tie up with industries, and should be conveyed in an impressive language. Likewise, he points out that approaches such as usage of magazine and journals, event engagements, and YouTube could be helpful for the promotion of any academic program or institution. Others have accorded a very high importance to the digital and virtual means to promote brand and image of an institution. It has been found in 
polls that many universities are now using social media as a tool to market their image and their operations (Hanover, 2014b). With this overview of literature on the place marketing and branding in the life of educational institutions, the next section discusses the methodology of the study.

\section{Methodology}

The study is designed as a mixed method exploratory case study involving both quantitative and qualitative analyses. Content and descriptive analyses of the admission and promotional ads for teacher education programs (e.g., BEd and MEd) published in the three major dailies (i.e., Mashriq, Aaj and Express) circulated from Peshawar have been carried out. Even though the dailies were published in Urdu, admission and promotional ads were either published in English or Urdu. The three dailies were defined as a "case" as espoused by Yin (1994). These dailies were clubbed as a case within the bounds of time and the issue at hand. The time bounds were set to be the admission cycle 2015-16. Admission ads appearing in these three dailies during May 01, 2015 to October 31, 2015 were selected for the study. In this article, where Urdu text is quoted from the admission ads, it has been transliterated ${ }^{1}$ using guidelines given by Pritchett (1994). As well, Urdu words are italicized for the purposes of clarity.

It was a Complimentary Mixed Method Design (Cameron, 2009; Small, 2011) in that the quantitative descriptive analyses were used as a compliment to the predominantly qualitative content analysis of the admission ads. Quantitative analyses included, among others, intensity of marketing in the form of relative frequencies from public and private sector.

Structural analysis of the admission ads lead to the creation of a data bank that included institution name, institution type, frequency of the ad, days and dates on which admission ads appeared for each advertiser and their strategies to reaching out to potential entrants including phone numbers (landline and mobile, website, email, social media, fax number), the enrichments in the ads such as being multi or bi-colored (black and white), online application facility, any attractions and incentives offered.

\footnotetext{
1 See http://www.columbia.edu/itc/mealac/pritchett/00ghalib/about/txt_translit.html for Urdu transliteration.
} 
The data was also analyzed for the page number on which the admission ad appeared within the daily.

Qualitative data was first coded openly followed by axial coding and generation of themes. The analysis focused on how well each advertiser was able to present its case by, for example, offering incentives, reaching out to potential entrants and ready help being available during the application process. Quantitative data analysis included aggregates of data across advertiser type (public and private), number of ads appearing in each Daily from a given advertiser, and the time spacing between successive ads appearing in the dailies. Since this was an exploratory study, simple descriptive statistics were calculated for the number of academic ads appearing in three dailies publishing from Peshawar, Khyber Pakhtunkhwa, Pakistan. Table 1 gives list of advertisers that appeared in these three dailies.

Table 1

Names (Pseudonyms), Type, and Location (KP = Khyber Pakhtunkhwa, $P=$ Provinces other than KP) of TEPs.

\begin{tabular}{llll}
\hline S\# & Name (Pseudonym) of the TEP & S\# & Name (Pseudonym) of the TEP \\
\hline 1 & Al-Noor University & 17 & Gandhara University \\
2 & Excellence University & 18 & Elementary Education College \\
3 & Wave Institute & 19 & University of Education \\
4 & Central Institute & 20 & Khatak University \\
5 & University of Intellect & 21 & International University \\
6 & Best University & 22 & Marhaba University \\
7 & Bright University & 23 & Central College \\
8 & Air College & 24 & Mardan Institute \\
9 & Open University & 25 & Oriental College \\
10 & Excellence Group of Colleges & 26 & Research University \\
11 & Modern University & 27 & College of Education \\
12 & Education Institute & 28 & Malam Jabba University \\
13 & University of Science and Technology & 29 & University of Asia \\
14 & Lucky Institute & 30 & Old University \\
15 & National University & 31 & Women University \\
16 & Elite University & 32 & University of Women \\
\hline
\end{tabular}

\section{Results and Discussion}

\section{Descriptive Analyses (Quantitative)}

As Table 1 shows, 32 (17 public and 15 private) TEPs advertised their program offerings in the three dailies during the study period. Twenty-four 
(24) of these advertisers were provincial entities working and functioning in/from Khyber Pakhtunkhwa. Remaining 8 entities were either from provinces other than KP or had a national presence in teacher training. Of the 24 entities in KP, 12 were public sector institutions and the remaining were private (Figure 1).

BEd (1 year) was offered by 14 advertisers that included 8 publics and 6 private TEPs (See Figure 2). BEd Elementary was specified by only 1 public advertiser. The same public advertiser also offered BEd 1-year Early Childhood Education (ECE), and BEd 1-year Secondary Education. MEd 1 year was offered by 9 advertisers, 4 of whom were private TEPs. Eight advertisers offered MEd 2-year program with an equal division among private and public TEPs. Five advertisers offered MA Education, two of whom were public. PhD related to the field of education was offered by 6 entities with an equal division among public and private actors. Similarly, MPhil related to a field of education was offered by nine entities including 5 public and 4 private TEPs. Other programs that were on offer were PTC, CT, Early Childhood Education (ECE), and Montessori. Only three private and one public TEP offered these programs.

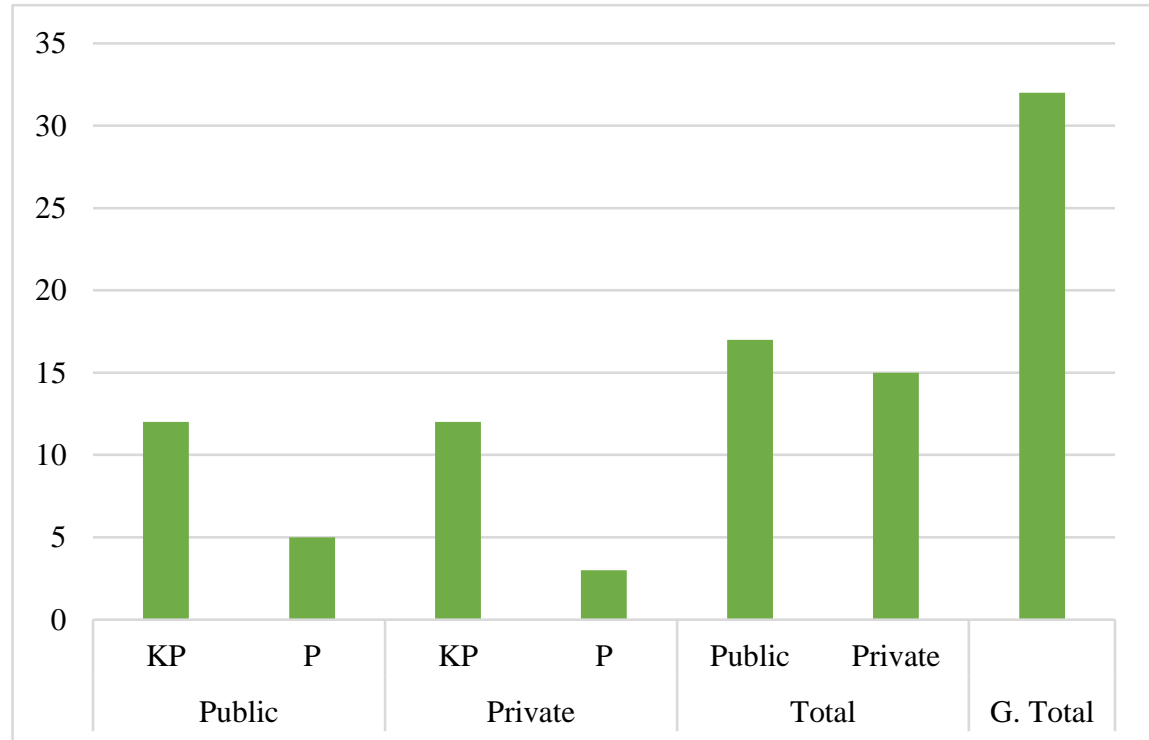

Figure 1: Type and Location of Advertisers (KP = Khyber Pakhtunkhwa, $\mathrm{P}=$ Provinces other than KP 
Nineteen advertisers shared eligibility criteria that were applicable in various teacher education programs. Out of these, 15 were public sector entities. Twenty-four advertisers had shown last date for application out of which 17 were public sector entities. Fifteen TEPs mentioned in their admission ad a test entry out of which 13 were from public sector. Seventeen advertisers had mentioned interview as a step in the admission process out of which 14 were from public sector. Nine TEPs offered MPhil in Education degree programs out of which 4 were public.

Four of the 32 advertisers had a social media platform to reach out. This included Facebook and Twitter. Other platforms such as Instagram were not seen in the admission ads. Of these four advertisers, who were all private TEPs, one had both Facebook and Twitter handles mentioned in their ads.

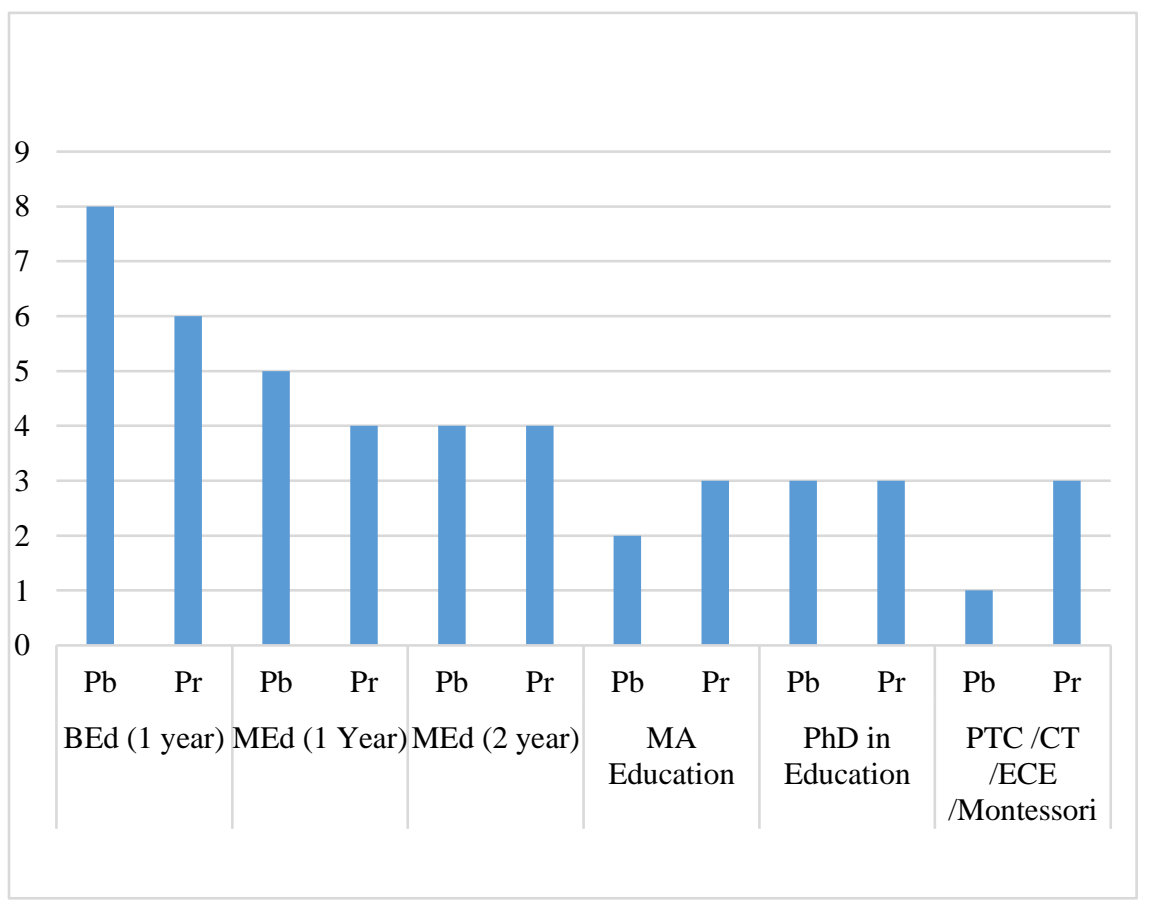

Figure 2: Teacher Education Programs Offered by Advertisers $(\mathrm{Pb}=$ Public, $\operatorname{Pr}=$ Private)

Twenty of the 32 advertisers had mentioned their URLs in the admission ads. Fax was not at all a preferred mode of communication as only 3 advertisers had mentioned it in their ads. Landline telephone 
numbers were the most favorite of all outreach devices as $100 \%$ of the advertisers had mentioned at least one such number whereas many published multiple landline numbers, most likely to cater to greater number of potential callers with any queries about education. Ten advertisers had also noted mobile phones in their ads, in many cases multiple numbers along with landline numbers. Twelve of the 32 advertisers $(37.5 \%)$ shared email addresses in their addresses in addition to other more traditional modes of reaching out to students.

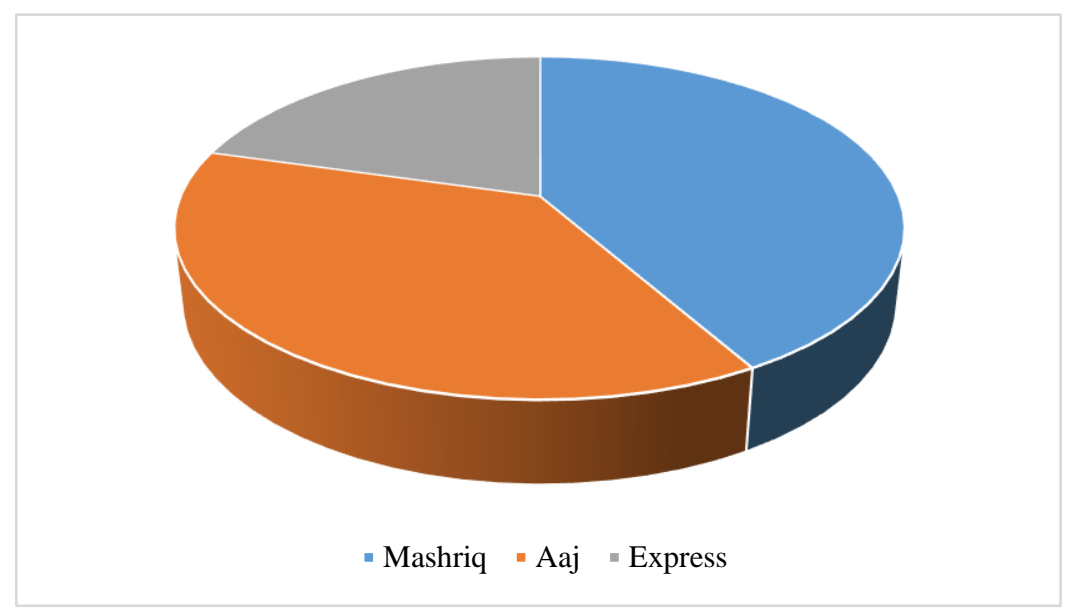

Figure 3: Market Share of Ads by Newspapers

Reach out was also studied in relation to how frequently the advertisers posted their ads in newspapers, which day of the week the ad was published, preferred choice of the Daily (i.e., Mashriq, Aaj, or Express), preferred page number within the daily, use of graphics particularly of photographs. The Daily Aaj appeared to be the most preferred outlet for admission ads by TEPs as $43.9 \%$ of all the admission ads appeared in this daily. This was followed by Daily Mashriq which received a share of $39.6 \%$ of the admission ads in the target admission cycle. Daily Express received only $21.6 \%$ of the market share in admission ads by Teacher Education Entities in the target period.

Sunday was the most favored day of the week with $29.7 \%$ of ad events occurring on this day. This was followed by Wednesday (15.8\%), Saturday $(13.9 \%)$, Monday (12.4\%), Friday (10.5\%), Thursday (9.57\%), and Tuesday $(8.61 \%)$. Private advertisers seemed more inclined to publish on Sunday compared with the public sector universities. Of the 62 instances 
of admission ads on Sunday, 43 (69.4\%) came from private TEPs. On the contrary, Saturday seemed a favorite day for public TEPs as 23 of the 29 (79.3\%) admission ads on this day came from public entities. Similarly, Friday and Tuesday were other favorite days for public advertisers as $63.6 \%$ and $61.1 \%$ instances of ads respectively appeared on these days from public advertisers. Rest of the week days had approximately equal presence of admission ads from both public and private sectors [Thursday (9/20 from private), Wednesday (17/33 private), and Monday (13/26 private)].

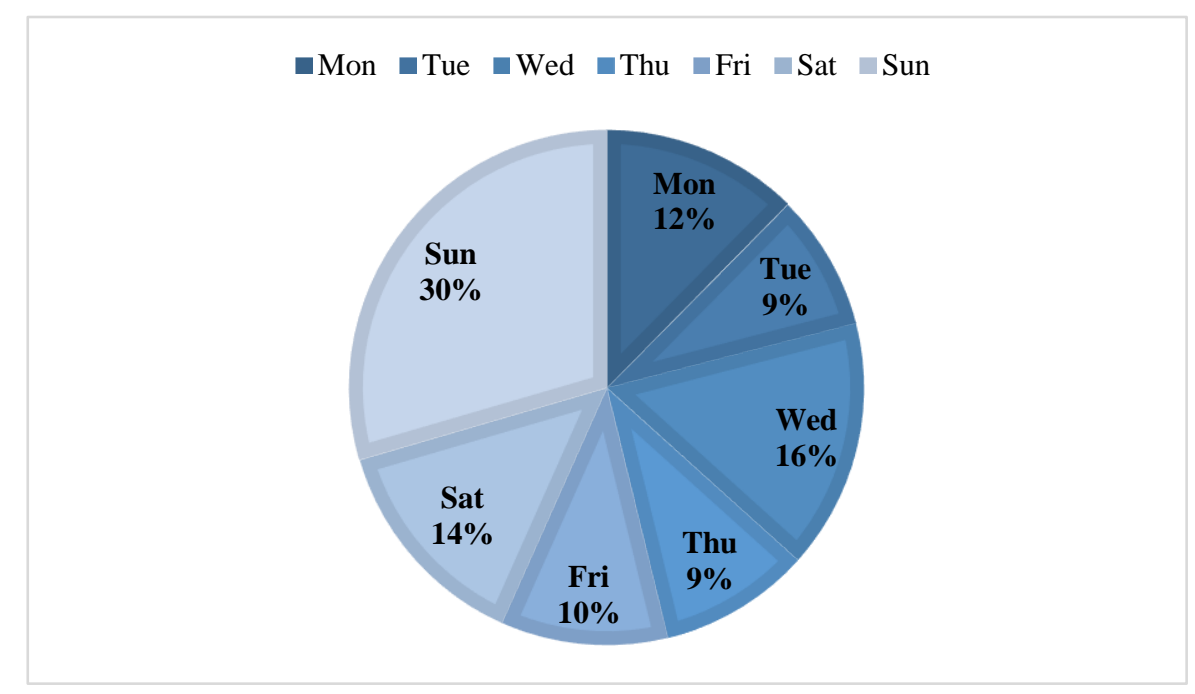

Figure 4: Day-wise analysis of admission ads

Page analysis in terms of which page most number of admission ads appeared on showed page 3 as a favorite location within the dailies with $69(33.01 \%)$ ads out of 209 appearing on this page (See Figure 1). This was followed by page $2(54 / 209)$ and page 12 (39/209) respectively. Pages 1,4 , and 11 received roughly similar number of ads with about 14-19 ads printed in these. There were 23 out of 54 instances of ads from public sector appearing on page 2; Public sector universities seemed to prefer page 3 with 45 counts of ads appearing on this page compared with 23 from the private advertisers. Page 12 saw a dominance of private advertisers with 29 of the 39 admission ads appearing from private sector on this page. 
With regard to colored ads, public and private advertisers roughly equaled with a slight edge to the public sector advertisers (8/15 colored ads). Seven advertisers used photographs in their ads that included photos of star performer students, campus or physical and human resources. Of these, 4 advertisers were private. There were 6 instances of featured pages, with promotional intents, where an advertiser published an entire or half of the newspaper page for self-promotion and admissions. These ads featured extensive portrayal of the vision, mission, values, resources and programs of the advertiser. These featured pages also carried a message note from the head of the institution such as the Vice Chancellor, the rector, or the president of the TEP. Four $(66.67 \%)$ of these feature pages came from private advertisers. Private advertisers outnumbered public advertisers by about 25 percent points (131 of the 209 ads making about $62.7 \%)$.

Figure 5: Ad Counts Per Page (Cumulative)

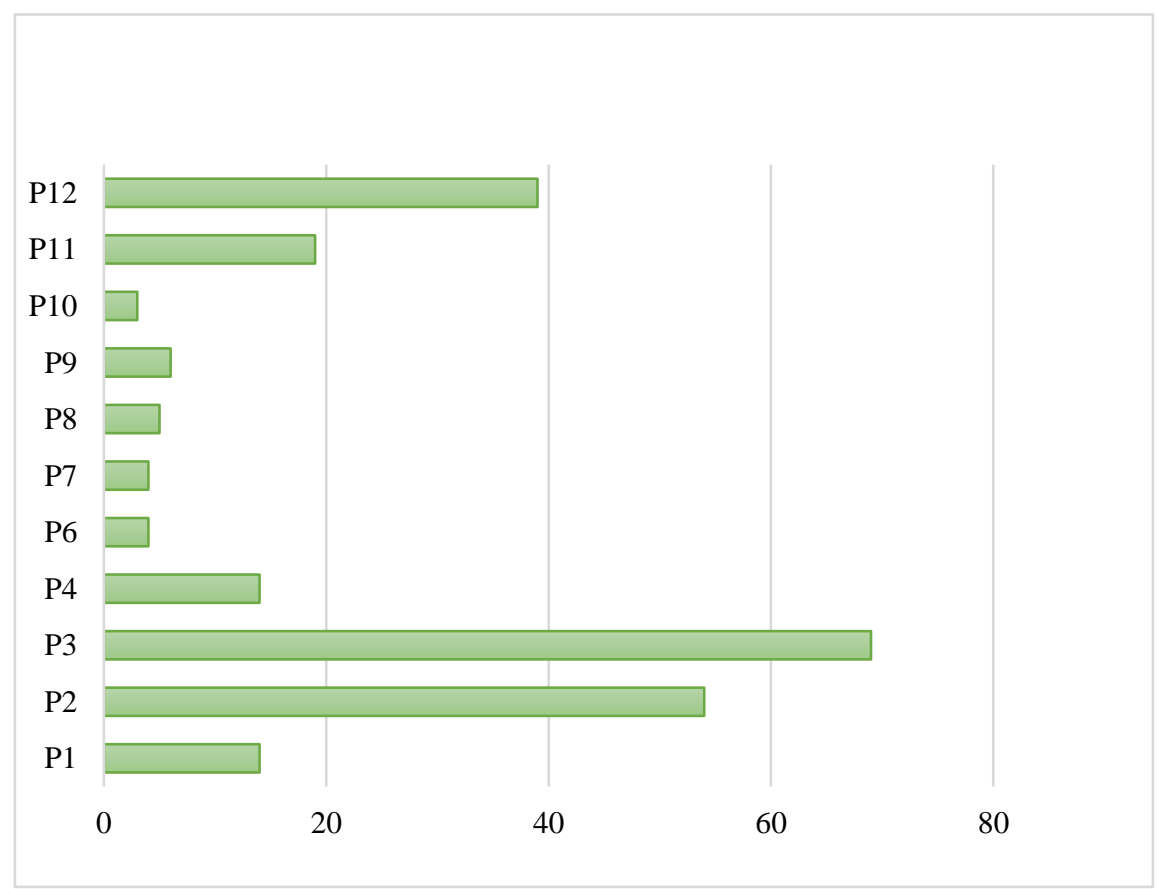

\section{Qualitative Results}

Admission ads were analyzed through constant comparison method to uncover themes and categories cutting across the institution types. Open 
and axial coding was adopted to generate categories and themes. These analyses yielded five themes on how well the advertisers were able to get their message across to the pool of potential applicants.

\section{We are 'unique'}

One of the themes that emerged out of the open coding of data was the claim that many of the advertising entities were unique in many ways. The uniqueness was axially analyzed for common elements. Axial analysis showed that universities and degree awarding institutes had a heightened vision of themselves. As an evidence to support their claim they offered various features. One of the frequently used feature of uniqueness was the ranking that the Higher Education Commission of Pakistan accorded to these TEPs. Not all the advertising entities offered this evidence though. One university claimed being unique in the following way:

By the Grace of Al-Mighty Allah: According to the recent Higher Education Commission ranking, Al-Ain (Psuedonym) University is ranked no 1 in KP in private sector universities. (General category), ranked 6 in the all private universities of Pakistan (general category), ranked 25 in the all private and public universities of Pakistan (general category). Passion to design futures. Chartered by the government of KPK and recognized by Higher Education Commission (HEC). [Adm Ad Sept. 14, P2, Daily Mashriq]

Other advertisers made similar assertions though in much concise manner. For example:

"NACTE, HEC se mānzūr shudā" [English Translation: "Recognized by NACTE, HEC"]. (Adm Ad Sept. 03, P3, Daily Express)

Top class education in a vibrant environment driven by research and innovation. (Adm Ad Oct. 09, P3, Daily Māshriq)

Yet other entities claimed uniqueness through such slogans as, With motto of quest for excellence the public sector university by GOVT of KPK invites applications on prescribed form for admission to the following programs. (Adm Ad October 21, P3, Daily Aaj). 
Thus, being recognized and certified by the HEC and NACTE (National Accreditation Council for Teacher Education) and being a public university seemed as the selling points when claiming 'uniqueness' by these advertisers. As shown in the quantitative analyses, many of the private advertisers published their ads in colored texts and photographs which appeared to be an effort to enhance the elements of uniqueness.

\section{We Support Your Education}

Education, teacher education including, has become increasingly expensive over the years in Pakistan. Thus, educational support has become a feature of many TEPs in the country. A common theme that emerged out of the data was the element of financial aid and scholarships that the advertisers widely used as an incentive to attract potential students. For example, one advertiser said:

Mustahiq tālibāt ke liye fees meñ ri 'âyat, FATA kī tālibāt ke liye mukammal muft ta 'Tim. (Adm Ad June 05, P3, Daily Mashriq)

English Translation: Fee concessions for deserving female students, completely free education for female students from FATA (Federally Administered Tribal Areas, which are now merged with the KP).

However, such provisions did not come free of conditions. Almost invariably, the performance in the examination came out as the primary criteria for eligibility:

$\mathrm{T}$ alent scholarships 1000/- to 5000, 780 se ziyāda mārks lene wāluñ ke liye dākhila fee meñ $40 \%$ ri 'âyat 800 se ziyāda lene wāluñ ke līye dākhila +tutition fee meñ 40\% ri 'âyat (Adm Ad. Jul 09, P2, Daily Mashriq)

English Translation: For students scoring 780 marks and above, talent scholarships worth 1000-5000 rupees', 40\% subsidy for candidates scoring more than 800 marks plus $40 \%$ subsidy in admission fee.

Others conditioned that such an assistance will be given on need basis: Financial assistance is available to those in need. (Adm. Ad. May 03, P4, Daily Mashriq). 
An important dimension in this theme is the use of metric to define 'talent' in pursuits of new entrants. It appeared that these TEPs focused on high test scores in some external standardized examinations as a primary metric to define talent and to offer financial incentives. While the test scores are important in measuring student competence in cognitive domains, a lot of what successful teachers do in classrooms is also driven by their non-cognitive traits such as being able to relate to students in meaningful ways, and to preserver in the face of challenging dynamics in classrooms. The TEPs seemed to focus only the cognitive part in attracting potential future teachers thereby leaving out significant determinants of teacher effectiveness in the non-cognitive part.

\section{We Reach Out Better}

An important theme that emerged in qualitative analyses was the "reach out" of the advertising entities. A variation was seen across admission ads in terms of how well the advertising agency made an effort to reach out to the aspiring candidates. In this regard, helping prospective candidates understand the application mechanism appeared to be an underlying effort on the part of TEPs to help the aspirants in smooth sailing through the admission process. If the TEPs could be placed on a spectrum of 'reach out' with the most supportive on the right and least on the left, universities on the right offered students to apply online whereas those on the left had a tedious procedure for securing admission forms with some even levying a fee to purchase the application form. Entities falling somewhere in the middle had mentioned a point of contact to seek help. Such a point of contact would include an email address, a telephone number (landline and mobile) and in rare cases a fax number. Those having a downloadable form had a website mentioned where aspirants could log on and access information about the advertiser and the admission procedure. Thus, reaching out better appeared as an effort by many advertisers to attract aspiring candidates. In this domain, as shown in the quantitative analyses, private advertisers were more robust in giving multiple options to reach out including telephone numbers (with mobile and landline numbers), online applications and social media presence.

The reach out was also analyzed with respect to how the advertisers made efforts to access the marginalized. To illustrate this, one advertiser had the clear intention of reaching out to the marginalized:

Two seats for afghan nationals, 7 seats for FATA \& Baluchistan, 1 seat for university employee's children, 1 seat for Armed forces, 1 seat for 
hafiz quran,1 seat for Disable (Adm Ad Aug 17, Supplement Page 1, Daily Aaj).

Fee subsidies could also be subsumed under this theme as an overt effort to reach out to the distant and marginalized:

FATA kī tālibāt ke liye mukammal muft ta 'lìm; (Adm Ad. June 5, P3, Daily Mashriq)

English Translation: Completely free education for female students from the FATA.

Many public TEPs also mentioned a certain form of quota based on how close or far an applicant resided. Other factors that were considered for admission quotas were the employment and ethnic status of the applicants.

At the same time, with fewer exceptions, advertisers in both private and public categories levied some form of monetary fee to apply for a place with them. This trend was less accentuated with the private sector entities. While this suggests that admission process incurs financial levies on the advertisers, they try to close this financial gap through contributions from the applicants. In many cases, this practice may bar potential applicants from applying in the first place especially those coming from lower socioeconomic strata. With teacher education and teaching an already low-paying and low-status profession in the country, prospective entrants with greater potential of being a teacher or a teacher educator may find it less attractive to apply in comparison to other disciplines such as engineering, medicine or business.

\section{We Have Better Resources}

With only few exceptions, every advertising entity did not leave a chance to highlight the elements and features that made them apparently attractive in the ad itself. This approach was mostly seen with the private sector institutions. The advertisers highlighted such resources as availability of hostel, particularly for girls, transportation facilities, computing facilities and libraries to attract potential entrants. It is noteworthy that physical resources were used to attract potential applicants whereas no advertiser, with few exceptions, highlighted teachers as their strength. General absence of 'quality teacher educator' in the ads probably hints at a serious handicap with the TEPs. If quality 
teacher educators are not in place in these TEPs, all other indicators of 'better' resources appear only as superficial glossing placed in the ads. Absence of quality teacher educators as a key human resource in the ads syncs with the larger observation of the generally low quality of teacher education in the country. Does this mean that the branding and marketing of teacher education is essentially built often on secondary indicators of quality such as transportation and hostel facility? If the TEPs do not have the 'quality' to sell, they are probably duping the prospective entrants into a profession that demands rigorous training.

\section{Conclusion}

Quantitative analyses showed that the private TEPs exercise a dominant presence in the print and electronic media as explored in the three dailies circulated from Peshawar. We also find that the private TEPs are employing multiple tools to enhance their reach to potential applicants. This was reflected in their non-orthodox approaches to advertising and branding including use of mobile phones, emails and social media platforms. Qualitative analyses suggest that the advertisers make an effort to portray an image of themselves that may resonate well with the potential entrants. This includes presenting a softer image of being a passionate and caring place where future teachers may like to enroll themselves. The advertisers did not seem to miss the chance to portray themselves as a place of excellence where competence and merit is rewarded. Such a tone, however, was reflected more in the admission ads from private TEPs than public.

Quite often, public advertisers preferred ads that showed only the minimum requisites of an application process. In such cases, it appeared that the advertising and branding office, if any, seemed to care much less on portraying a positive image of the institution and focused more on the administrative and logistical aspects of the application process. In this regard, public sector TEPs may need to think of developing appropriate mechanisms to formulate marketing and branding strategies that bring them in the spotlight in the huge market for prospective teacher educators. Admission ads from public sector TEPs can be made more attractive in ways that highlight any positive aspects of the public education system. While this may seem a gigantic task given the often tarnished image that any public entity holds in Pakistan, it is vital that public TEPs are able to capitalize on all the positive aspects of their existence if they have to remain in the business many decades down the line.

A case may also be made on the truthfulness and validity of all the lofty claims that the private TEPs make in their admission ads. As the saying goes, all that glitters is not gold. In other words, though the private 
TEPs may be able to attract potential entrants by designing and promoting catchy labels and slogans, the ground reality may be at variance with such media portrayals. This is attested by the sustained urgency shown in successive education policies to improve quality of teacher education, particularly in relation to quality of teacher educators. With few exceptions in both public and private sectors, teacher education suffers from a lack of quality in almost all facets from curriculum to quality of teacher educators. Specifically, National Education Policy 2017-25 (Government of Pakistan, 2017) indicts teacher education in the country by saying that "Teacher educators in most of the teacher education institutions, particularly in the affiliated colleges and new universities lack proper qualifications and relevance to their job" (Ministry of Federal Education and Professional Training, 2017, p. 62).

This raises the important question of: are TEPs in Pakistan marketing and selling brands that are of low or superficial quality? If the answer is yes, which very likely is, it has serious and long term implications for the quality of teachers and teacher education in the country. One obvious way forward to address this question can be to institute appropriate mechanisms for monitoring and accountability of what the TEPs are marketing and branding in their admission ads. For example, in the words of Black (2008) are TEPs fulfilling their branding and marketing promise as reflected in the deep and meaningful learning experiences for students in classrooms? Furthermore, just as branding and marketing in general consumer products involve censor and regulatory checks before being put to public consumption, education ads should go through much more rigorous checks. These checks should go well beyond the minimum standards of any censorship regime and into the actual content and its relevance to the assessed quality of the advertiser. This may be a long haul in the first place, but given the future costs involved, monitoring quality of teacher training, both in the public and private sectors, may begin with monitoring what they are selling to the potential entrants. To conclude, if the objective of TEPs is to attract potential and promising talent that can deliver on the claims of their quality, they will have to portray through marketing and branding an image of teachers and teacher education in ways that can at least show this profession in the positive limelight in comparison to other professions such as business, medicine, engineering, law, commerce and others. The current branding and marketing of teacher education does not appear to come close to these fields and disciplines. Further studies may be conducted on such aspects to explore the parity between the branded image and true quality delivered by the TEPs. It may also be studied as how well a particular brand image lead to what quality of entrants, and ultimately the quality of graduates in teacher education programs. 


\section{References}

Academy of Educational Planning and Management [AEPAM], (2018). Pakistan Education Statistics 2015-16. Retrieved May 03, 2017 from http://library.aepam.edu.pk/

Balmer, J. M. T. (2001). Corporate identity, corporate branding and corporate marketing. Seeing through the fog. European Journal of Marketing, 35(3/4), 248-291.

Bamoriya, H. (2013). Branding an academic institute: A holistic exercise. Retrieved May 02, 2017 from http://www.indianmba.com/ Faculty_Column/ FC1531/fc1531.html.

Black, J. (2008). The branding of higher education. Retrieved May 05, 2017 from http://www.semworks.net/white-papers-books/thebranding-of-higher-education.php.

Cameron, R. (2009). A sequential mixed model research design: design, analytical and display issues. International Journal of Multiple Research Approaches, 3(2), 140-152.

Chapelo, C. (2010). What defines successful university brands? International Journal of Public Sector Management, 23(2), 169-183.

Darling-Hammond, L., Holtzman, D. J., Gatlin, S. J., \& Heilig, J. V. (2005). Does teacher preparation matter? Evidence about teacher certification, Teach for America, and teacher effectiveness. Education Policy Analysis Archives, 13(42), 1-38.

de Heer, F., \& Tandoh-Offin, P. (2015). Exploring the Benefits of Branding Universities: A Developing Country Perspective. IUP Journal of Brand Management, 12(4), 58-71.

Dooley, R. (2013). College branding: The tipping point. Retrieved April 20, 2017 from https://www.forbes.com/sites/rogerdooley/2013/ 02/05/college-branding-tipping/\#67e0219417ff.

Gupta. (2010). Marketing \& branding higher education: Issues and challenges. Retrieved April 25, 2017 from

http://www.freepatentsonline.com/article/Review-Business-Research/ 237533606.html.

Hanover Research (2014a). Trends in Higher Education marketing, recruitment, and technology. Retrieved May 8, 2017 from http://www.hanoverresearch.com/media/Trends-in-HigherEducation-Marketing-Recruitment-and-Technology-2.pdf. 
Hanover Research. (2014b). Why marketing strategy matters in higher education. Retrieved May 02, 2017 from

http://www.hanoverresearch.com/2014/07/22/why-marketing-strategymatters-in-higher-education/.

Idara-e-Taleem-o-Aagahi, (2016). National Education Policy 2016 consultations. Retrieved May 03, 2017 from

http://itacec.org/nep_declarations.php?pgid=3.

Khan, A., 2010. A case study exploring perceived professional development needs for secondary school administrators in Pakistan. Unpublished $\mathrm{PhD}$ dissertation. Administrative and Policy Studies, School of Education, University of Pittsburgh, Pennsylvania.

Ministry of Federal Education and Professional Training. (2017). National Education Policy 2017-25. Retrieved from http://www.moent.gov.pk

Ministry of Education [MoE]. (2009). National Education Policy 2009. Retrieved May 03, 2017 from http://unesco.org.pk/

Papadakis, J. (n.d). Increasing visibility and student retention: Marketing within a departmental academic advising office. Retrieved April 28, 2017 from http://www.nacada.ksu.edu/Resources/Academic-AdvisingToday/View-Articles/Increasing-Visibility-and-Student-RetentionMarketing-Within-a-Departmental-Academic-Advising-Office.aspx.

POPESCU, A. I. (2012). Branding cities as educational centers: The role of higher education institutions. Management \& Marketing Challenges for the Knowledge Society, 7(03), 493-512.

Pritchett, F. W. (1994). Nets of awareness: Urdu poetry and its critics. Berkeley, CA: University of California Press.

Small, M. L. (2011). How to conduct a mixed methods study: Recent trends in a rapidly growing literature? Annual Review of Sociology, $37,57-86$.

Sullivan, B. A. (2012). How to make a college an irresistible brand? Retrieved April 15, 2017 from

https://www.forbes.com/sites/forbesleadershipforum/2012/08/23/ho w-to-make-a-college-an-irresistible-brand/\#1b5f13bc2994

Teichler, U. (2003). The future of higher education and future of higher education research. Tertiary Education and Management, 9(3), 71-185. doi: 10.1023/A:1024472116331 
University Business. (2008). 50 best branding ideas: How colleges and universities are successfully creating and communicating their brands. Retrieved April 25, 2017 from

https://www.questia.com/magazine/1G1-190462820/50-best-brandingideas-how-colleges-and-universities.

Valtere, L. (2012). Branding in higher education: The concept of brand and key stakeholders. Jaunuju Mokslininku Darbai, 4(37), 150-155.

Yin, R. (1994). Case study research: Design and methods. Thousand Oaks, CA: Sage.

\section{Citation of this Article:}

Khan, G., Khan, A., \& Sultana, M. (2018). Marketing and branding of teacher education in Khyber Pakhtunkhwa, Pakistan: Teacher education providers' struggles for prospective entrants. Pakistan Journal of Education, 35 (3), 141-162. 